\title{
論說講 義
}

\section{螢光性及び燐光性物 孟の化學}

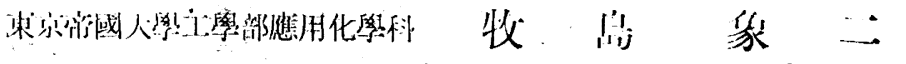

\section{1. 緒 言}

17 世紀の始めにイタリーのボロニア (Bologna) ひ V. Cascio-

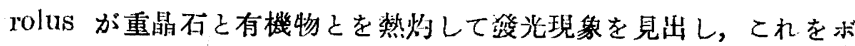
山ニアの石々名づけたのが発光性物質の最初である。その後 1886 件に俳人 T. Sidot が角閃石の粉末を $\mathrm{SO}_{2}$ ガ 久を通じつつ加熟し て憐光性物質を得て Sidot's Blende 子名うけた事が歷史的に有名 である。譶者は硫化バリウムを，後者は硫化亞鉛を主體とする不純 なる燐光性物質と洘へられる。その後佛人 Becquerel, 獨人 Le-

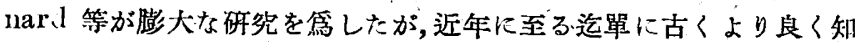
られた事柄として物理及び化學界の片隅に押し込められ何等の華々 しき将來を期待されなかつた。然るに1930 年代に至つて固體の量

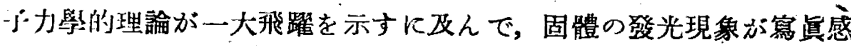
光現象，内部光電效果等之も密接な關俰にある事が明かとなり急に

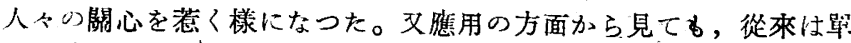
に發光塗料ともてささやかな用途を持つに過ぎなかつたが，近來著 しく重要性が高まつて來た。郎ち 1938 年以降より愃傅される樣に な.つた螢光放電燈(Fluorescent Lamp) 仗固體螢光物質を塗附した 放雪登であるが, 最も能率良く且色謨の自在な冷光源として恐らく は遠からず現在の白熱電燈を驅逐すべき運命にある。蓋しこれは照 明學界い一大革命上なつて算しからら。文テレヴィジョンの技術的 進步も最近目覺しきものがあるが，そ心最後の段階を支配するもの

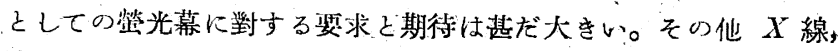
陰極線工學，特殊計器，軍用通信等方面に特殊用途が推けつつあ る。てれ等の方面はその技術が谷々闹度且精密化して來るらで，從 來想像もしなかつな樣な装求が相次で生じ, 從てかかる特殊な物質 の活用が必装となつて來るのである。以上の樣な譯で發光性物質の

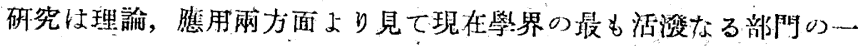

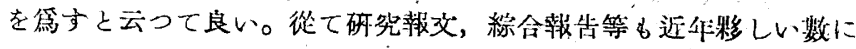

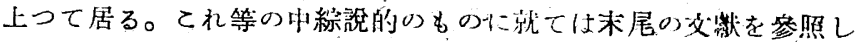
て頂きたい。1)

發光物質の製造を化學工業い立場より見るならば，勿論その性貿 上製造量は僅少であるが，技術的に見て甚だ興味がある。贸占原料 に装求される極度に宫い純度や，極めて微妙なる熟處理の片法等は 最も高度の技術を装する無機化學工業の1部門である。不純物の溜 入を 10 萬分の 1 以下に保ち，酸化を避けつつ $1000^{\circ} \mathrm{C}$ 内外で望み の熟虎理を施すと云子事は，筫驗空では左程困難ではないが工業的 には甚だむづかしい問題である。文純學問的に見るならば整光及び

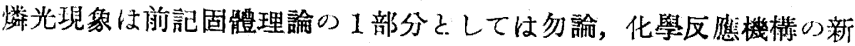
しい研究方法として特に注目すべきのである事を附け加へて置き 度い。

\section{2. ルミネセンスと冷光}

物體（固體，液體，载體何れでも良い）が盆溫に熱せられ，熱的

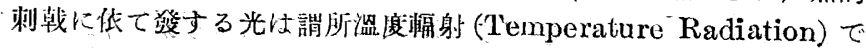

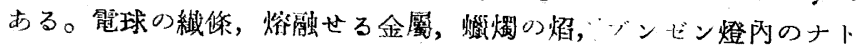

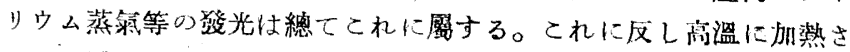
れ奴物體が热, 光, 電場, 「線, 除極線等の放射線の刺战, 或け化 學變化，音波，機械的刺战等に依て旅する光をルミネ七ンス (Lumi-

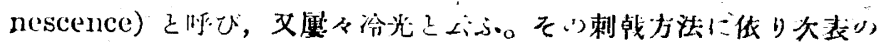
如く稓ふに分類されて度る。

第 1 裴一ルミ我センスの分類

留光的原因名稱望例

\begin{tabular}{|c|c|c|c|}
\hline & 熟 & Thermo-luminescence & 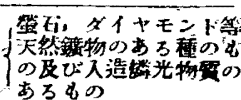 \\
\hline$\pi$ & 光 & Photo-luminescence & 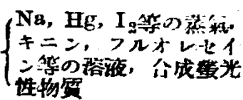 \\
\hline ミ & 笔武 & Electro-luminescence & 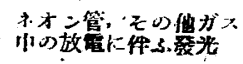 \\
\hline * & $\begin{array}{l}X \text {-線, 陰極線, } \\
\text { 隄極線, } x \text { - } x \text { 線等 }\end{array}$ & $\begin{array}{l}\text { 灷ふの名を冠せる } \\
\text { luminescence }\end{array}$ & 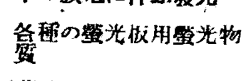 \\
\hline 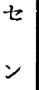 & 化學變化 & Chemi-Iuminescence & 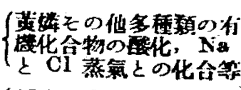 \\
\hline ᄌ & & Sono-luminescence & 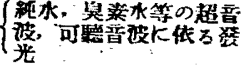 \\
\hline & $\begin{array}{l}\text { 結晶の生長又は } \\
\text { 破署 }\end{array}$ & $\begin{array}{l}\text { 犬々Crystal-及びTribo- } \\
\text { luminescence }\end{array}$ & 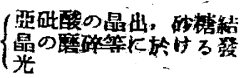 \\
\hline & 生活現象 & Bio-luminescence & 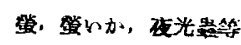 \\
\hline
\end{tabular}

以上各種のルミネ七ンスの中でがスの笙氣發光がネオンサインそ の他に使はれる事は周知の如くであり、攵儿ミネセンスの中当外

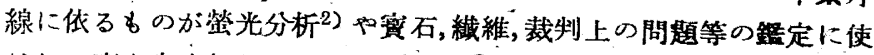
は机る事も良ぐ知られて居る。併し最も重装なのは既に连へた如々

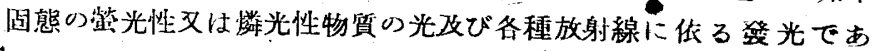

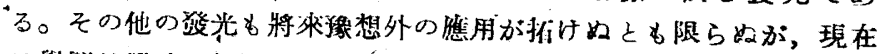
は學閣的興味の範罣を出九い。

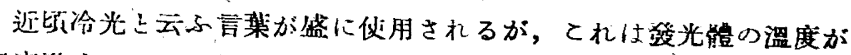
溫废梫光に此心て低い身から来て居るのである。溫㡲發光と暴り，

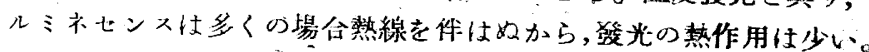
俳し紹對的の泠光は理㜅上不叮能であつて, 到來する輻射線を熱土

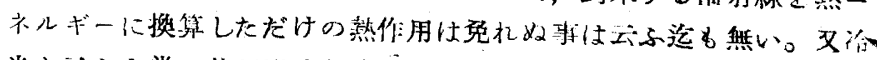

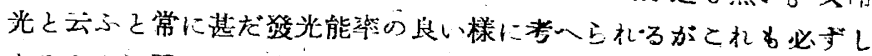
もそらとは限ら好。多くのルミネセンス，特に化學發光は其機上

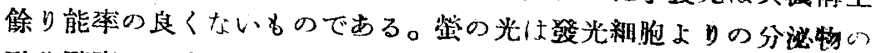
酸化醂素の存在に於ける酸化發光之考一ら机るが，近頃の考に依る

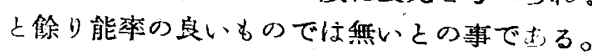

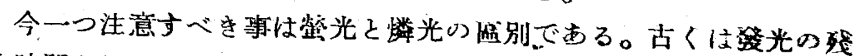
光時間を以て成别し，螢光は残光時閒の殆ど無いもの，憐光はこれ の相當あるものとして居た。作し䖝光計 (Fluorometer) が進步する につれて所謂螢光にも $10^{-9} \sim 10^{-2} \mathrm{sec}$ 程度の垡光のある事が的か

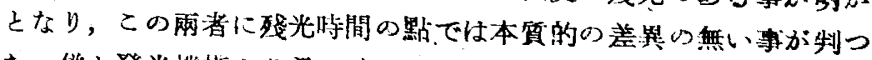

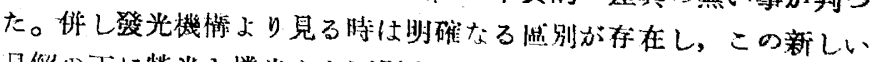

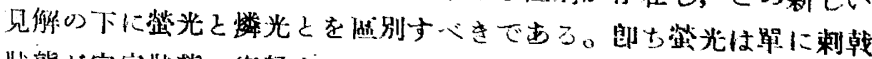

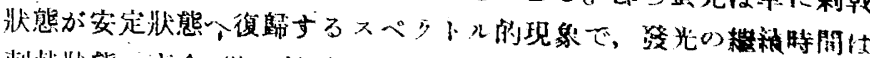

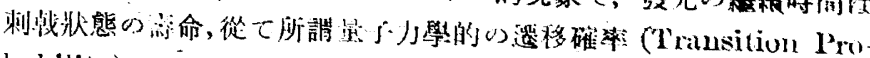

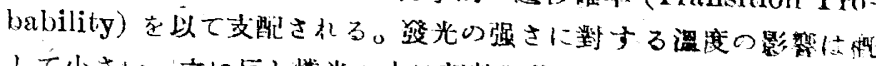

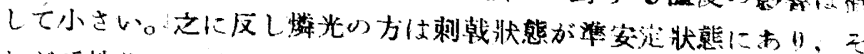

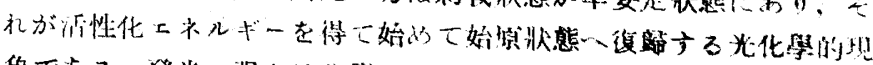

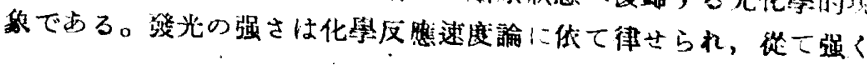


温度の影笊を受ける。或種の燐光性物質は蓄光狀態が 1 ヶ月以上に る及ぶすのがあり，加熱する時は之を放出して Thermo-luminescence を與へる事がある。然るに ZnSe 憐光體の如きは常温に於け 了赤色登光は維繶時間は $1 / 50 \mathrm{sec}$ 程度で外見上螢光の如くに見える

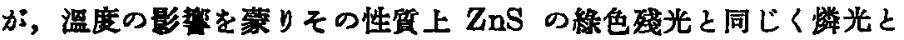
稱すべものである。

\section{3. 主要なる固體螢光性及び燐光性物瓷}

第 2 表に固態發光物質の一括した分類表を示す。發光物得には純

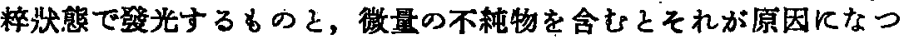
て發光するるのと 2 種類がある。

\section{第 2 表 竐光物質の分類}

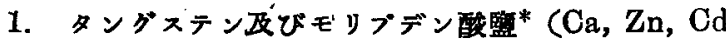
等の監)

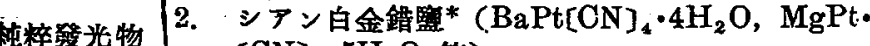
$[\mathrm{CN}]_{4} \cdot 5 \mathrm{H}_{2} \mathrm{O}$ 等)

(Reinstoff- $\left\{3 . \quad\right.$ ウランル化合物 ${ }^{*}\left(\mathrm{UO}_{2}\left[\mathrm{NO}_{3}\right]_{2} \cdot \mathrm{KNO}_{3}\right.$ 等)

luminoph- 4. 硫化物及び酸化物 ( $\mathrm{ZnS},{ }^{*} \mathrm{ZnO}$ 等)

ore) $\quad$ 5. 八ロゲン化物 $(\mathrm{Cu}, \mathrm{Ag}, \mathrm{Mg}, \mathrm{Zn}, \mathrm{Cd}, \mathrm{Hg}, \mathrm{Tl}$ $\mathrm{Sn}, \mathrm{Pb}, \mathrm{Sb}, \mathrm{Bi}$ 等の監化物，臭化物）

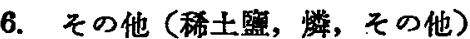

(1. “ “Lenard” 發光性物質 (Be, $\mathrm{Mg}, \mathrm{Ca}, \mathrm{Sr}, \mathrm{Ba}$, $\mathrm{Zn}, \mathrm{Cd}$ 等の酸化物，硫化物，七レン化物等を校 䯘とし，これに少量の融劑及び微量の重金属，稀 土篮等を發光中心乙して含むもの)

2. 八ロダン化物發光性物質（ハロゲン化アルカリに $\mathrm{Ag}, \mathrm{Cu}, \mathrm{Tl}, \mathrm{Pb}, \mathrm{Mn}$, 稀士. 觪等を少量含む子 の)

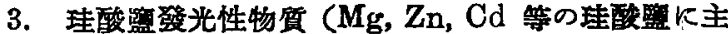
附活發光性 物質 (Frem dstoff-luminophore)

\section{として Mn を微量に合むもの)}

4. 䇪化物及び炭化物發光性物犋 $\left(\mathrm{Be}_{\mathrm{s}} \mathrm{N}_{2}, \mathrm{AIN}, \mathrm{BN}\right.$, ダイアモンド,カーボランダム等が適當なる微量 の不純物を含を時)
5：發光性ガラス（ウラン化合物，稀土筧等を含むが ज $\pi$ )

6. その他の無機鋅物 (ルビー，スピネル，䖝石，方

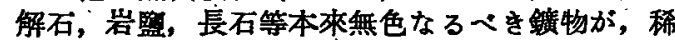
土類, Mn, $\mathrm{Cr}$ 放射線に依了分解生成物等を含む 場合)

7. 有機發光性物犋 (アンスラセン, 安息香酸等多く の芳香族化合物; $\mathrm{H}_{3} \mathrm{BO}_{3}$, ぜジチン等に少量の色 素を添加したもの；多くの高分子量化合物等〉

第 2 表中純粹發光性物質反於て *記したるのは常溫で明かに留 光するが，他のbのは主として液體些氣程度の低溫飞於て始めて登 光の認められるるのである。以下主要なるものに就て概略を記す。

$\mathrm{Ca}, \mathrm{Zn}, \mathrm{Cd}$ 等のタングステン酸監は赫度の高い程良く發光し， 且燒成して良く結晶せしめないと發光能力が弱い。 $\mathrm{CaWO}$ は は 435 $m \mu$ (青紫)附近门極大を持つた發光を示し，從て寫道作用が强いの で從來より $X$-線用篔感紙として使はれて居る。CdWO4は 390〜 $490 \mathrm{~m} \mu$ K强い發光帶を， $520 \sim 600 \mathrm{~m} \boldsymbol{\mu}$ К弱い發光带を持ち青白く 光ろ。共に發光の縸緇時間は甚だ短い。發光の原因は 4 個の酸素に 图まれたW.及は MoKもりとされて居る。硫化亞鉛等に比べれ ば發光强度は迷に低いので漱次使はれなくなりつつある。

シアン白金錯監，ウラニル監等は高價な事，有毒な事，比較的分 解し易い等の原因で現在は全く宽用には供せられない。これ等る

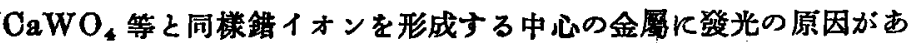
ろ。これ等の金呞は周图に配位した基に依て他の原子の影警から遮

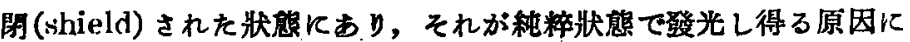

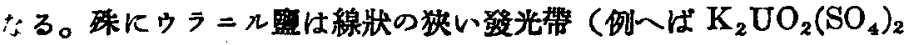
は常温飞於て $492,513,536,560,588 \mathrm{~m} \mu$ の 5 ヶ所）を與人るので 著名である。これ等の發光はその機棈上䖝光に属する。

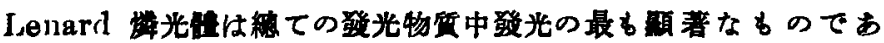

ろ。その中でる殊に硫化物がぞ5である。酸化物は發光の刺戟に多 揾のエネルギーを要し，㢱光が概して短波長（或すのは紫外部にあ ろ）で且弱い。邓セレン化物は概して發光が長波（或ものは赤外部 にある)に過ぎ，残光弱く蓄光量も少い。硫化物です $\mathrm{Be}, \mathrm{Mg}$ は 發光弱く, $\mathrm{Ba}$ は蓄光量少く, $\mathrm{Cd}$ は發光が赤外部にある。著しい 發光を示すのは專ら $\mathrm{Ca}, \mathrm{Sr}, \mathrm{Zn}$ の硫化物及び $\mathrm{ZnS}-\mathrm{CdS}$ の固溶 䯠である。

これ等の硫化物登光體は極めて純粹な硫化物母體に 1〜10 mo'\% 程度の骶劑 nogen, Zentrenmetall)を加一, $1000^{\circ} \mathrm{C}$ 前後で燒成して遗る。融

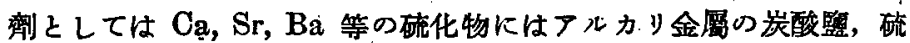

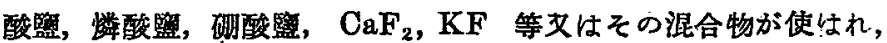
$\mathrm{Zn}$ 及び Zn-Cd 系にはアルカリ又はアルカリ土金屬の八ロゲン化 物が使はれる。中心金屈としては多數が使はれるがその作用から甽 瞭に之種類が區別される。第 1 類は $\mathrm{Cu}, \mathrm{Ag}, \mathrm{Hg}, \mathrm{Sn}, \mathrm{Pb}, \mathrm{Sb}, \mathrm{Bi}$ 等酸性溶液より $\mathrm{H}_{2} \mathrm{~S}$ に依り着色硫化物を沈激する重金屬である。

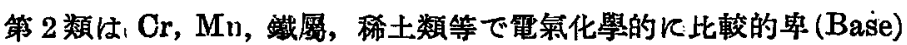
な金屬で，且着色監を與人るものである。アルカリ,アルカリ土類，

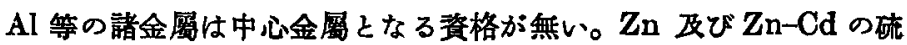

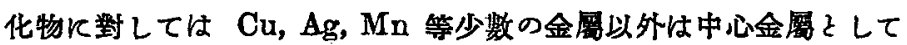
作用乙ない。

Lenard 憐光體の發光機構は憐光性であつて著しい琖光を示す。 第 1 類中心金屬に依る發光帶は一般に幅が廣く，且母體が戀化する とそれに雔じてずれる。例人ば $\mathrm{Bi}$ は最す强い登光性を與人るが， CaSBi は青紫，SrSBi は青，BaSBi は綠黄に光る。之K反し第口 類中心金虽はその金屬に特有の概して狹い發光帶を與人，母體の種 類に影響される事が少い。例人ば $\mathrm{Mn}$ は $\mathrm{CaO}, \mathrm{CaS}, \mathrm{SrS}, \mathrm{ZnS}$ 何 れに對しです黄橙色の發光帶を與へる。殊に著しいのは稀土類で $\mathrm{Sm}$ の如きは母體に依て殆ど變化しない数組の線狀發光帶を與一

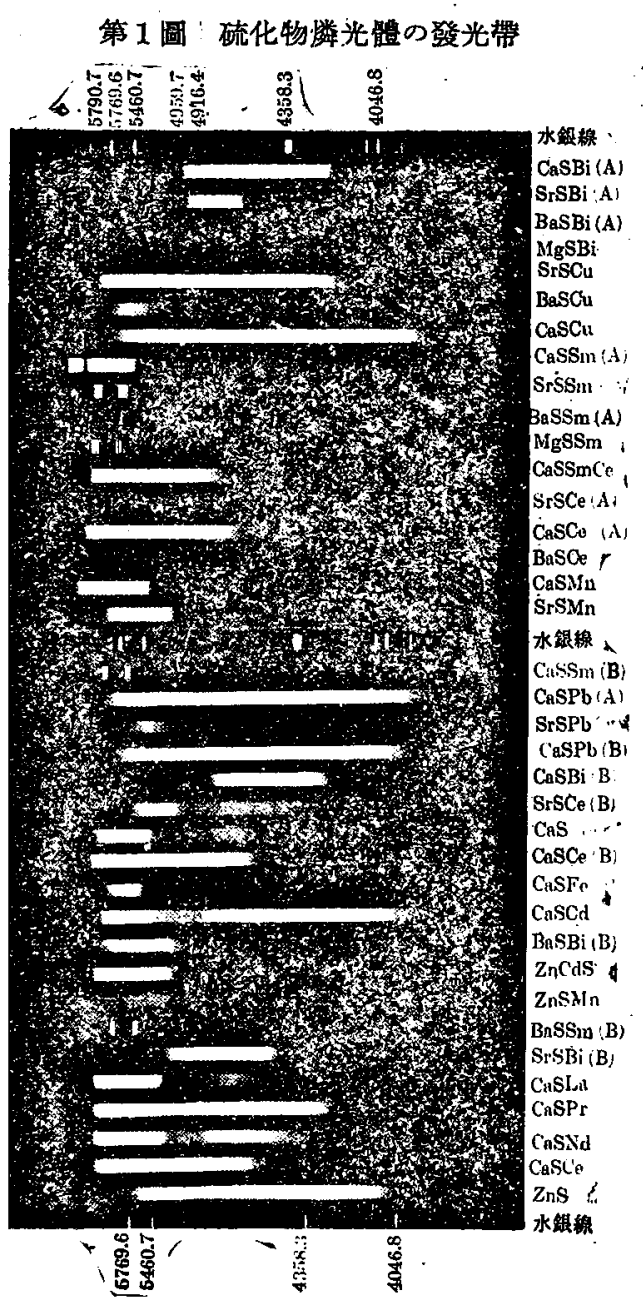
る。とれ等の事留 は發光機椿の考察 上極めて重要な事 唡である。第 1 漁 注著者の湘定した 主嬖なる硫化物橉 光體の發光帶の例である。3) 融椡 の作用は甚だ微妙 で未詳であるが, 發光帶の波長分布 には餘り影響せ す，發光の强さ乙 び戥光時間に著し い影哲を與へる。

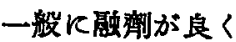
利いて燐光體の結 晶化が進む程發光 は强くなるが，發 光の減衰 (Decas, Abklingen) が速 くなる。その作用 が選擇的で，ある 種のものが格段に 有效であるが事多 い。融劑は醅結 晶の 2 次構造に大 きな影響を與人る むのを考一られ ろ。母鰽結晶の種 
類も大きな影憵を有し，母體結晶の格子佰数 (Lattice Constant) が大になる程發光帶が長波に傾さ, 且践光時間が短くなる。この點 溫度を上昇せしめた事と似て居る。

$\mathrm{Zn}$ 及び $\mathrm{Zn}-\mathrm{Cd}$ 系のものは $\mathrm{Ca}, \mathrm{Sr}, \mathrm{Ba}$ 系のものと稍々趣を異に

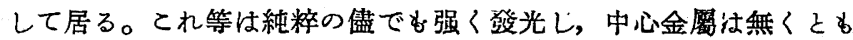
良い。又既述の如く中心金屬として有效に作用するものの數が甚だ 少い。併して不純物としての Fe, Co, Ni 特に Co 及び Ni K著し く敏感で，てれ等が 10 萬分の】含まれても既に發光能が著しく害 せられる。との雼作用の篇，ての系統の發光體の製造には純度が特 に問題となつて來る。かかる毒作用は發光帶の中の燐光性のものに 强く作用するが，螢光性のものには比較的弱い。依ててれを利用し て Ni を $\mathrm{Zn}$ 乙び $\mathrm{Zn}-\mathrm{Cd}$ 系螢光體の殘光を殺すのに用ひ，抑制劑 (Nickel Killer) と呼んで居る。ZnS の發光帶は極大が $460 \mathrm{~m} \mu$ (青紫, 螢光性) 之 $520 \mathrm{~m} \mu$ (綠, 燐光性) 附近の 2 r所佀あるが, CdS を添加する事に依て連續的に長波に移す事が出來, DdS のみ そなれば逐に赤末を過ぎて赤外に及ぶ。從て $\mathrm{ZnS}$ とdS との配 合比を橔へる事に依て青より赤迄の任意の發光色を與へる事が可能 である。又それ等の機峨的混合物に依てスペクトルの7色中に無、 色，例人ば白，ばら色，・リーム色等の發光色のものを造る事る可 能である。かかかる利點の他に，ての系統のるのは刺戟エネルギーが 他の何れの種類よりも少くて良い事, 發光が强力なる事, 化學的に 瀑氣，風化等に對して安定なる事等の利點のある篇に最す實用性が 大きい。後述する發光物質の用途の總てに對し遠からずての系統の ものが他の總てのもの $\left(\mathrm{CaWO}_{4}\right.$, 珪酸驰鉛等)を驅逐するのではな いかと考へられる。貫用上のものは大部分 $\mathrm{Cu}$ 㕛は $\mathrm{Ag}$ を中心金 屬として用ひて居る。放射線, 光線等に依て光化學的崩疃作用を受 け劣化し易いのが最大缺點である。この點に關しては融劑, 添加劑， 燒成條件が重大な影锌を持つ事を忘れてはならない。

珪酸監の中珪酸亞鉛は天然に Willemite $\left(2 \mathrm{ZnO} \cdot \mathrm{SiO}_{2}\right)$ として知 られて居るが,一般に $\mathrm{Zn}, \mathrm{Cd}, \mathrm{Mg}, \mathrm{Be}$ 等の珪酸監に中心金屬と して Mnを加へたるのが合成されて居る。Mn を含む珪酸亞鉛の 場合は $525 \mathrm{~m} \mu$ (綠) 附近に比較的短い殘光を持つた發光體があり， 倚 $\mathrm{Mn}$ が多くなれば, $600 \mathrm{~m} \mu$ 附近(橙)に弱心帶があり，低溫に於

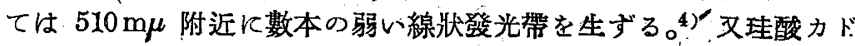
ミゥムは橙色儿發光する。てれ等に於て $\mathrm{ZnO}$ 圣は $\mathrm{CdO}$ と $\mathrm{SiO}_{2}$ との比は必ずしも一定して居ない。これ等の發光體は刺戟に多量の エネルギーを要するので, 發光塗料等の目的には殆ど使一ない。乙 かし化學的並に光化學的に安定な事, 割に低速度の陰極線 $(300 \mathrm{~V}$ 位) で良く發光する事，稍短い紫外線，例一ば水銀燈の共鳴線 $2537 \AA$ 等に良く感ずる事等の爲に，テレヴィジョン，罃光放電燈 (後迅)等の發光劑として殊に米國に於て好んで使はれる。併し ZnCd 系のものが今後一層進步すれば，てれに比して特に取立てて云 ぶ゚き特長があるとは考へられない。

ハロゲン化物發光物質はハロゲン化アルカリス中心金屬と、して $\mathrm{Cu}, \mathrm{Ag}, \mathrm{Hg}, \mathrm{Pb}, \mathrm{Tl}$ 等のハロゲン化物を微量に加へて飺融し，或 は放射線，アルカリ金屬蒸氣等の作用で着色せしめ,所謂 U 又は F-中心（U-or F-Centre）を生ぜしめたものである。この系統は Pohl, Gudden, Hilsch 等の一派に依て盛に研究せられたるので, 發光體が透明な單結晶として得られ. (Lenard 憐光體は粉末しか得 られぬ), 分光的研究に特に好都合であ る。又母體のハロゲン化アルカリが結 晶化學的良く研究されて居る事る大 きな利點で, 理論的取扱には最も適し て居る。一般に管光及び燐光の機潔は 甚だ厄介な問題であるが，乙の方面か ら最す有力な手掛りが得られつつある。 一般には Lenard 燐光體とハロゲン 化物燐光體々は全く别種のものと考一 て居る様であるが，著者はこの兩者は
同種のものであり，同樣の機櫣の下に說明さるべきすのであると考 一て居る。併しハロゲン化物燐光體は多量の刺戟エネルギーを必献 とし，發光帶も大部分紫外部にあり，今の所殆ど赛用には供せられ ない。

\section{4. 固體螢光及び燐光性物質の用途}

てれ等固態の發光物質の用途は大體 2 種に分けられる。第 1 は各 種の螢光スクリーンである。郎ち $X$-線, $\boldsymbol{\gamma}$-線等の透過試驗用薙光 板，㓌極線を用ふるオッシログラフ，電子䢙折用の䖝光板，X-線分 析に用ひる增感用スクリーン，Braun 管，特にテレヴィジョン用の 䖝光板等がこれに屬する。これ等は何れも甚だ高いエネルギーで刺 戟するから發光物質が崩壤を起工劣化乙易い。從て耐久性と發光の 强い事は共通の要求であるが，その他に種々い泩交がある。例へば テレヴィジョン用には成るへく加速電遮の低い電子流で良く發光す

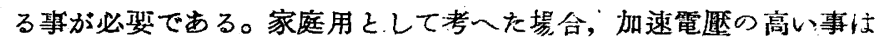
甚だ危险であり，又受影裝置を著しく高價ならしめる。その他發光 物質の色調が白色光に近い事, 發光の殘光時間汃眼の殘像時間より 長くない事等が要求される。その他紫外線，赤外線等を用ひる秘密 通信用螢光板として用ひられると聞くが，その詳紏は一般に不明で ある

一般に透視用 $\boldsymbol{X}$ 線螢光板には發光の强い $\mathrm{Zn}-\mathrm{Cd}$ の硫化物が， $X$ 缐增感紙には粒子が細てく䉣真作用の强い $\mathrm{CaWO}_{4}$ 等が，陰極 線用には安定な珪酸笽が使はれるが，後の 2 者も漸次 $\mathrm{Zn}-\mathrm{Cd}$ の硫 化物に置き換一られつつある。

第 2 は照明用である。從來も發光又は蓄光塗料として時計の文字 板, 各種の標識, 復寫用光源 (“Luminophor”なる商品名で發賣 されて居るなどに使はれて居た。近頃は計器の目盛, 或璉の標裁 等特殊の方面一益々重要性を增しつつある。てれ等の塗料は一般に 謜起用として微量のラヂウムを含むが，ラヂゥムの高價な事と，そ の放射線に依る發光物質一の破壤作用の篇飞何か良、代案の出現が 切實に望まれて居る。

次に 1938 年顷より出現して最近異常の注目を萑いて居るものに 螢光放電短 ${ }^{5}$ (Fluorescent Lamp) がある。これは水銀, アルゴン, ネオン等を封入した低茞がス放電管の内壁に適當な䖝光物質を鉒附 したもので，ガス放電に依るガスの發光と，その祭に生ずる紫外線 に依て萿起された螢光物質よりの發光々を利用したものである。發 光管の構造, 始動の方法, 使用電腿の高低等に依て種々の型がある が，米國 G. E. 會邧より出して居るるのは電嬁線より直接點燈出 來, 急光色, 白色その他種々の色の發光を與いるものがある。これ は管狀電球で酸化物を被覆した 1 對の整陰極を具人; 管內に水銀々 アルゴンが封入してある。室溫が $21 \sim 27^{\circ} \mathrm{C}$ の時使用中の發光管の

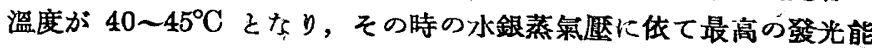
率を生ずる樣に設計されてある。螢光物質は現在 $\mathrm{Zn}, \mathrm{Be}, \mathrm{Cd}$ 等 の珪酸監を主體としたものを用ひ配合に依て種々の色を出ざせて居 る。使用電厭 $110 \mathrm{~V}$ 附近に於てランプ熋流は $0.3 \sim 0.5 \mathrm{~A}$ 程度であ る。

螢光放電燈の照明效率は甚だ高く，從來の何れの光源より侵唀 である。一例を示せば $40 \mathrm{~W}$ ガス入タングステン電稓と維色, 白色 及び慧光色螢光放電燈々の效來を比較すれ ば第 3 表の如くになる。

第 3 表 白熱電燈々䖝光放電燈との效本比較

\begin{tabular}{|c|c|c|c|c|c|c|c|c|c|c|}
\hline & \multirow{3}{*}{$\begin{array}{c}\text { 色溫度 } \\
{ }^{\circ} \mathrm{K} \\
\end{array}$} & \multirow{2}{*}{\multicolumn{2}{|c|}{ 全 輻 }} & \multirow{2}{*}{\multicolumn{2}{|c|}{ 射 線 }} & \multirow{3}{*}{ 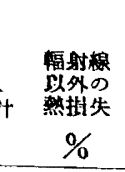 } & \multirow[b]{3}{*}{$\begin{array}{l}\text { 照明数就 } \\
\text { lumant } \\
\text { Watt }\end{array}$} & \multicolumn{3}{|c|}{ 可梘光線の没長分布 } \\
\hline & & & & & & & & & & \\
\hline & & $\begin{array}{c}\text { 可視光線 } \\
\%\end{array}$ & $\begin{array}{c}\text { 赤外線 } \\
\%\end{array}$ & $\begin{array}{c}\text { 外線 } \\
\% \\
\end{array}$ & $\begin{array}{c}\text { 合 } \\
\% \\
\end{array}$ & & & $\begin{array}{l}3800- \\
5000 \mathrm{~A} \%\end{array}$ & 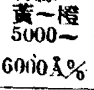 & $6000-\%$ \\
\hline $\begin{array}{l}\text { タシグステン霆燈 } \\
\text { (40W，がス） }\end{array}$ & 2780 & 7.4 & 61. & 0.04 & 68.5 & 31.5 & 11.9 & 0.62 & 1.86 & 5.6 \\
\hline 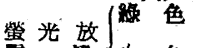 & - & 11.8 & 0.02 & 0.27 & 12.1 & & 60 & 1.79 & 9.8 & 0.19 \\
\hline (17.5W) 燈 $\{$ 白 & 3500 & 11.7 & 0.11 & 0.18 & 12.0 & 約 88 & 30 & 2.4 & 4.8 & 4.4 \\
\hline 茎老色 & 6500 & 12.4 & 0.08 & 0.26 & $12.7 \prime$ & & 30 & 4.8 & 4.4 & 3.2 \\
\hline
\end{tabular}


㴧ちタングステン電球が全入力の $7 \%$ 俆りを可視光として利用す

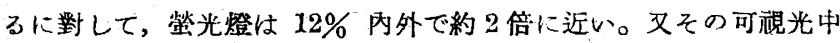
に泊熱電燈に比し視感度の高い線及び黄を多〈含む故にWatt 當

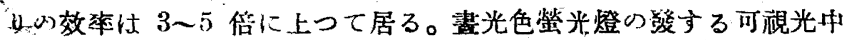

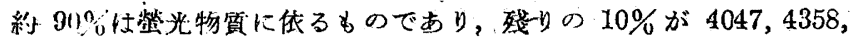

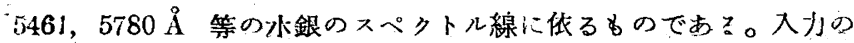
$88 \%$ は可旗光以外に浪費されるが，その中 $45 \%$ は篮光機模そのも

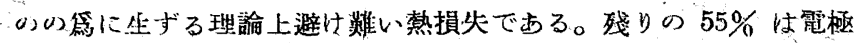
い加熱，管壁心溫度上昇等に使はれ，乙れ等は何れも結局對流，傳

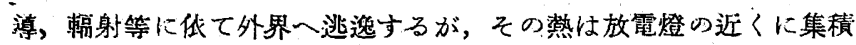

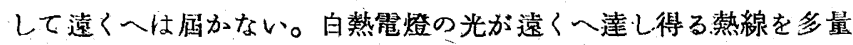
に件ふ事と比へると䖝光燈の光は涂程“冷い”之云つて良い。

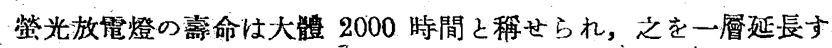
る事，放笔燎に固有のチラッキが若干ある事，载溫の餘りに低い所

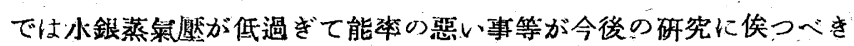

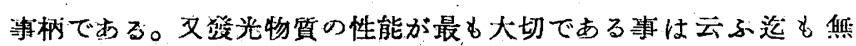
w。

\section{5. 結 言}

以上で發光物質に關する極く概略を远べたつもりであるが，设光

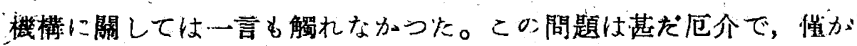
の紙數では到底述べる事は出來ない。現在闾體論の中心䦗題として 極めて多數の報交が次ふに發表さ礼るが未だ完全なるのは出て居な

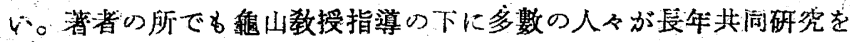
行つて居るが，造からずその結果を筑表し得る荤びになつて居る。 著者は從來の發光機構に關する研究には次の諸點に缺陷があると考

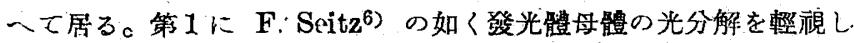
或は至然考虑に入れて居巨㰠事である。硫化亞鉛などが特に發光し 易い原因が，ZnS が光分解を受け易い事之密接な關係のある事を認 識する必要があるc 次に C.J. Milner ${ }^{7}$ ) の如く固體の帶域論 (Zone Theory）のみを以ててれを說明せんとする方法である。發光現象 ば結晶の不規則简所 (Lockersiellen)が主として關與するものであ るからエネルギー帶域との交涉は比較的僅少でなければならな い。第 3 に贯驗的研究が概して不足である。墢光帶の分光的研究は

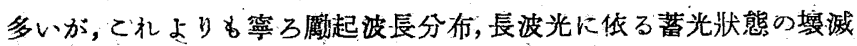
(Auslöschung), 光電導現象等の研党が必要である。开研究が統計 的でなけ札ばならない。如何に精緻な研先方法を以て測定を行つう b，澌定試料が特殊のものであり，少數であうては無意味である。 设光物質の性質は製造條件に敏感に支配されるが故に同一種の試料
であ多數の測定を必荘とする。且设光は特殊な物質た固有な現象で は無く，廣沉大結晶性物質の通有性だからである。Lenard 一泒の 成大な測定值を以てしても，吾々が發光機棈の考察上「役に立つ」 數做は極めて貧弱之云はねばならない。

現在の螢光及び憐光の理諭では侵秀な發光物質を製造する焦い指

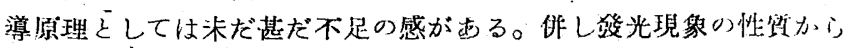

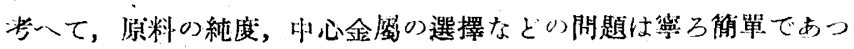

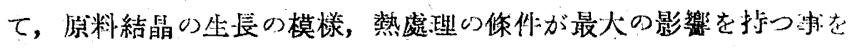
强嗬して真をたい。

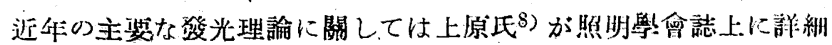
に紹介してあるから參照して戴き度い:。你近く管氣化學誌上にも箸

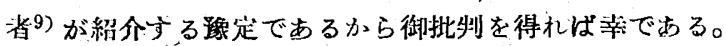

1) 著 書

$$
\text { 文，虔 }
$$

1'. Pringsheim: Fluoresenze und Phosphorescenz(1928)

II. : Handbuch der Physik XXIII/1

M. Curie: Luminescence des corpes solides

M. Déribéré: Les applications -pratiques de la luminesceuce (1938)

E. Rupp: ' Leuchtmassen und ihre Verwendung 綜說を揭げた雜点

Trans. Faraday Suc., 1439, 35, No. 1, Jan “Chemiluninescerce'

Acta Physica Polonica, 5, "Rapport sur la Photo'uninescence” 然昐學會誌, 昭利 $5,24,5$ 月 “罃光特斾”

2）例-ば後藤秀弘：日化，昭和 $13,59 ， 199,203,365,371$, $547,625,797,805$; 泠光, 昭利 15 , 第 3 輯, 46

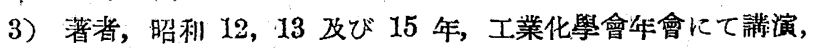
詳細は近く發表の渙定

4) J. T. Randall, Nature, 1938, 142, 113

5）藤田文太郎，照明學會雚誌，昭和 $15 ， 24 ， 159$ B. T. Barnes, W. E. Forsythe \& W. J. Karash, G. L. Rev., 1939, 42, 540

6) F. Seitz, J. Chem. Phys., 1938, 6, 150

7) C. J. Milner, Trans. Faraday Soc., 1939, 35, 101

8）上原康夫，照明學會㒕詀，昭栦 $15,24,125$

9）著者，電载化學誌上に連繶揭載中の「固體の物理化學】中心 1. 章として近く揭載の鿷定。 